\title{
EVALUASI RISIKO DALAM RANTAI PASOK CABAI DI KABUPATEN SUMENEP
}

\author{
Sustiyana ${ }^{1^{*}}$, Iswahyudi ${ }^{2}$ \\ 1Prodi Agribisnis, Fakultas Pertanian Universitas Islam Madura, Jl. Pondok \\ Pesantren Miftahul Ulum Bettet, Pamekasan, Indonesia \\ 2Prodi Agroteknologi, Fakultas Pertanian Universitas Islam Madura, Jl. Pondok \\ Pesantren Miftahul Ulum Bettet, Pamekasan, Indonesia \\ Email korespondensi: Sustiyana.nirbana@gmail.com
}

Naskah diterima: 16 Juni 2020 Direvisi:13 September 2020 Disetujui terbit: 7 Oktober 2020

\begin{abstract}
ABSTRAK
Setiap komoditi pertanian mempunyai risiko, terutama pada komoditi strategis yang mempunyai daya beli tinggi seperti komoditi cabai. Risiko dialami oleh tiap stakeholder yang berperan dalam rantai pasok mulai dari produsen, pedagang, hingga konsumen, sehingga keberagaman risiko tersebut perlu dikaji secara komprehensif. Penelitian ini menggunakan metode purposive dengan analisis deskriptif kualitatif dengan teknik brainstorming dalam Focus Group Discussion pada stakeholder terkait. Berdasarkan hasil penelitian risiko tertinggi dialami oleh petani yaitu sebesar $41 \%$, pengepul $16 \%$, pedagang besar $23 \%$, pedagang eceran $13 \%$, dan konsumen $7 \%$.
\end{abstract}

Kata kunci: Cabai, Rantai Pasok, Risiko.

ABSTRACT

Each agricultural commodity has its own risks, especially in strategic commodities that have high purchasing power such as chili commodities. Risks experienced by each party that plays a role in the supply chain from producers, traders, to consumers, so the diversity of risks needs to be studied comprehensively. In this study using a purposive method with qualitative descriptive analysis with brainstorming in Focus Group Discussion of stakeholder. Based on the research results, the highest risk experienced by farmers is $41 \%$, collectors $16 \%$, wholesalers $23 \%$, retail traders $13 \%$, and consumers $7 \%$.

Keywords: Chili, Supply Chain, Risk

\section{PENDAHULUAN}

Komoditi cabai mempunyai

fungsi strategis dalam mempengaruhi perdagangan hortikultura karena minat masyarakat untuk mengkonsumsinya sangat tinggi. Hal ini sesuai data Kementrian Perdagangan (2019) yang menyebutkan bahwa konsumsi cabai rawit terus mengalami peningkatan yaitu tahun 2017 sebesar 2,95

(kg/kapita), tahun $2018 \quad(3,00$ kg/kapita), dan tahun 2019 (3,05 kg/kapita). Komoditi ini digunakan sebagai bahan utama dalam pembuatan produk seperti sambal maupun sebagai bahan pelengkap beragam makanan. Konsumennya pun berada pada semua kalangan sehingga permintaan terhadap 
komoditi cabai selalu tinggi. Hal tersebut mendorong petani untuk menanam cabai dan pedagang untuk terus menyupplai kebutuhan cabai kepada konsumen industri maupun konsumen rumah tangga (Badan Pusat Statistik, 2011)

Rantai pasok merupakan sistem untuk menyalurkan produk dari produsen hingga konsumen (Indrajit \& Djokopranoto, 2002). Tang (2006) mendefinisikan manajemen rantai pasok adalah pengelolaan dari 3 aliran utama yaitu aliran produk, aliran uang, dan informasi di setiap lembaga yang berperan dalam rantai pasok. Jaringan kerja tersebut terdiri dari beberapa stakeholder yang terlibat dalam saluran pemasaran.

$$
\text { Pada praktik kerjanya, }
$$
stakeholder dalam rantai pasok mempunyai risiko yang beragam tergantung dari fungsi pemasaran yang dilakukannya. Menurut Bredell (2008), Manajemen risiko dalam rantai pasok diartikan sebagai sistem pengelolaan dari setiap lembaga yang terlibat dan terintegrasi dalam rantai pasok baik internal maupun eksternal.

Produk pertanian termasuk cabai mempunyai risiko yang lebih sulit daripada produk lainnya. Hal ini disebabkan oleh adanya ketidakpastian di berbagai aspek baik di sisi produsen atau petani maupun aspek pengaruh lingkungan kerja dalam rantai pasok.
Dengan adanya kebutuhan dari masyarakat yang tergolong tinggi tekadang tidak diimbangi dengan kuantitas produksi yang kontinu karena memang karakteristik produk pertanian juga tergantung dengan musim sehingga secara langsung mempengaruhi harga.

Fluktuasi harga cabai juga tinggi, hal ini dipengaruhi oleh banyak faktor risiko yang dihadapi oleh petani hingga pelaku pemasaran lainnya dalam rantai pasok. Risiko - risiko yang dihadapi oleh anggota rantai pasok komoditi cabai perlu diidentifikasi agar dapat diketahui secara lengkap dan mendalam. Hal ini serupa dengan yang dikemukakan oleh Austin (1992) bahwa dalam manajemen risiko rantai pasok terutama pada komoditas pertanian memiliki perbedaan dengan komoditas non pertanian. Perbedaan tersebut disebabkan karena produk pertanian memiliki sifat perishable (mudah rusak), dipengaruhi oleh lingkungan dan alam di setiap proses penanganannya sejak tanam hingga panen dan bentuk/ukuran yang tidak seragam.

Tujuan dari penelitian ini adalah meminimalkan terjadinya risiko dengan pola manajemen yang tepat sehingga dapat memperlancar kinerja rantai pasok cabai tersebut. Pola manajemen resiko dalam rantai pasok tersebut bisa ditentukan dengan adanya sistem pengambilan keputusan yang 
tepat sesuai dengan hasil dari identifikasinya.

\section{METODE PENELITIAN}

Penelitian ini dilaksanakan di daerah sentra penghasil cabai di Kabupaten Sumenep yaitu Kecamatan Bluto dengan metode purposive (sengaja). Menurut data Dinas Pertanian Tanaman Pangan, Hortikultura, dan Perkebunan tahun 2019, daerah tersebut memiliki hasil produksi cabai yang paling tinggi dari kecamatan lainnya di Kabupaten Sumenep yaitu sebesar 8.296 kwintal.

Responden dalam penelitian ini terdiri dari petani, pengepul atau tengkulak, pedagang besar, pedagang eceran, dan konsumen. Metode penentuan responden menggunakan metode snowball sampling sehingga jumlahnya sesuai dengan anggota rantai pasok yang termasuk kategori expert (ahli atau berpengalaman di bidangnya). Penelitian ini dilaksanakan dari bulan November 2019 hingga Maret 2020.

Dalam mengevaluasi risiko dalam rantai pasok terdapat dua metode utama yaitu metode secara statistik dan metode berdasarkan pendapat para ahli di bidangnya (Klimov \& Merkuryev, 2008). Metode dengan menggunakan statistik dan deterministik dikenal dengan istilah model evaluasi risiko kuantitatif, sebaliknya model evaluasi risiko kualitatif menggunakan pendapat orang yang expert pada lembaga yang terlibat dalam rantai pasok. Pada penelitian ini menggunakan metode analisis deskriptif kualitatif dengan ditunjang data persentase risiko dalam rantai pasok cabai. Analisa risiko juga dilakukan dengan teknik brainstorming dengan stakeholder (petani, pedagang perantara, dan konsumen) dalam Focus Group Discussion (FGD)

\section{HASIL DAN PEMBAHASAN}

\section{A. Kondisi Rantai Pasok Cabai di Kabupaten Sumenep}

\section{Product Flow (aliran produk)}

Pada saat musim tanam cabai, aliran produk dimulai dari petani sebagai produsen, kemudian setiap harinya akan dijual kepada tengkulak atau pengepul terdekat sesuai dengan hasil panen pada hari itu. Proses jual beli ini dilakukan secara langsung karena sebagian besar petani tidak memiliki tempat (gudang) yang bisa menampung cabai dalam kapasitas besar, sehingga setelah panen petani akan langsung menjualnya ke tengkulak yang paling dekat dengan tempat tinggalnya. Selanjutnya pedagang besar akan mendatangi para tengkulak yang letaknya tersebar di banyak tempat untuk membeli produk tersebut. Tetapi tidak menutup kemungkinan bahwa para tengkulak yang akan mendatangi pedagang besar. Aliran produk cabai 
selanjutnya adalah pada pedagang eceran. Pembelian ini dilakukan dengan harga jual yang berbeda - beda sesuai dengan musim atau harga pasar saat itu dan jenis cabai tersebut (cabai merah lebih mahal daripada cabai hijau).

Konsumen dari cabai ini

beragam. Konsumen di daerah Kabupaten Sumenep biasanya adalah konsumen rumah tangga hingga industri kecil menengah terutama yang bergerak di bidang panganan. Produk cabai hasil panen petani di Kabupaten Sumenep juga disalurkan hingga ke daerah lainnya (kabupaten lain dan Pulau Jawa) yang konsumen akhirnya juga tidak jauh berbeda yaitu konsumen rumah tangga, IKM, dan industri besar yang berbahan baku cabai.

Alat transportasi yang digunakan oleh petani berupa motor yang bergerobak (viar) yang berkapasitas sedikit, sehingga kegiatan pemasarannya kurang optimal. Sedangkan untuk lembaga pemasaran lain yang memiliki daya transportasi yang mendukung. Biasanya produk diangkut dan dikirim dengan menggunakan mobil bak terbuka atau truk yang hanya dimiliki oleh pedagang perantara yang bermodal lebih tinggi yaitu tengkulak maupun pedagang besar.

Saluran pemasaran cabai di Kabupaten Sumenep terdiri dari 3 saluran berikut ini:

Evaluasi Risiko dalam ....
Saluran 1 : Petani, Tengkulak, Pedagang besar, Pengecer, Konsumen.

Saluran 2 : Petani, Tengkulak, Pengecer, Konsumen

Saluran 3 : Petani, Konsumen

\section{Information Flow}

Pada sistem kerja rantai pasok memanfaatkan aliran informasi yang terintegrasi satu dengan lainnya. Contohnya ketika harga pasar cabai meningkat maka informasi tersebut akan sampai ke masing - masing stakeholder dengan cepat karena adanya saling komunikasi. Informasi tersebut melibatkan stakeholder dalam rantai pasok secara dua arah yang membahas tentang perkembangan informasi harga cabai baik di pasar tradisional dan pasar domestik, jumlah pasokan produk yang tersedia dan siap untuk dikirimkan, hingga informasi mengenai status pengiriman barang. Informasi yang akurat sangat mendukung tercapainya efisiensi dalam kinerja rantai pasok cabai ini.

$$
\text { Informasi mengenai harga }
$$

terbaru biasanya didapat oleh petani dari mulut ke mulut atau melalui media telekomunikasi seperti handphone. Sedangkan pada pedagang perantara, informasi harga didapat dari perkembangan harga pasar secara langsung.

\section{Financial Flow}

Aliran finansial berkaitan dengan proses keuangan yang 
disepakati antara pihak yang terlibat dalam rantai pasok karena terjadi fungsi pemasaran dengan melaksanakan proses pembayaran atas produk yang telah diperjualbelikan. Arah aliran ini berlawanan dengan arah aliran produk. Aliran keuangan bergerak ke belakang dari konsumen menuju pedagang perantara atau produsen/petani cabai. Pembayaran biasanya dilakukan secara tunai untuk menghindari risiko adanya penyalahgunaan kesepakatan.

\section{B. Analisis Risiko Rantai Pasok Cabai}

\section{Identifikasi Risiko}

Menurut Suharjito et al. (2010), Risiko yang dialami oleh usaha bidang pertanian terdiri dari Risiko lingkungan, teknologi, harga, pasokan, transportasi, pasar, produksi, informasi, mutu, penyimpanan, dan kemitraan. Faktor tersebut dapat dijadikan acuan dalam mengidentifikasi dan menganalisis risiko komoditi cabai di Kabupaten Sumenep. Berikut ini tabel yang menunjukkan identifikasi risiko yang dialami oleh tiap stakeholder dalam rantai pasok cabai di Kabupaten Sumenep:

Tabel 1. Identifikasi Risiko tiap Stakeholder Rantai Pasok Cabai di Kabupaten Sumenep

Evaluasi Risiko dalam ....

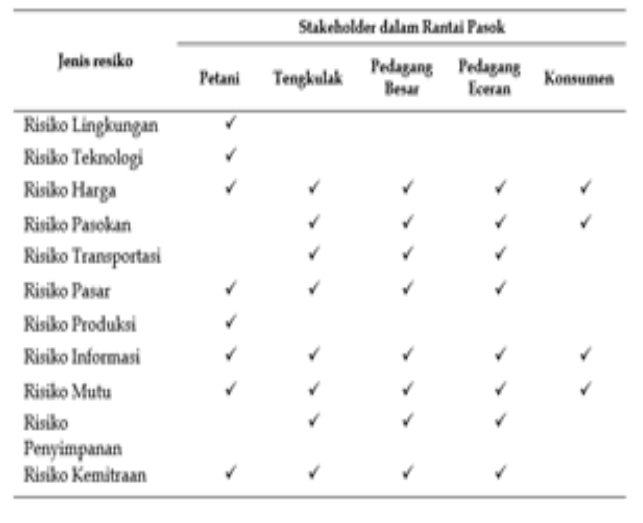

Sumber: Data primer diolah, 2020

Dari data tesebut dapat diketahui bahwa setiap stakeholder yang terlibat dalam rantai pasok mempunyai risiko hanya saja jenis faktor risiko yang dialami petani, pedagang perantara, dan konsumen berbeda, tetapi untuk jenis risiko yang dihadapi oleh pedagang perantara (tengkulak, pedagang besar, pedagang kecil) relatif sama hanya yang membedakan adalah persentasenya. Hal ini dipengaruhi oleh jumlah produk yang dijual.

\section{a. Risiko di tingkat petani}

Risiko yang dialami oleh petani lebih cenderung pada aspek produksi yaitu saat penanaman benih untuk disemaikan menjadi bibit. Hal tersebut dipengaruhi oleh faktor cuaca apabila terkena hujan dengan intensitas yang tinggi maka banyak bibit yang rusak dan membusuk sehingga mengurangi jumlah bibit yang akan ditanam di lahan utama. Buah cabai yang sering terkena hujan maka kualitasnya akan menurun oleh sebab itu petani banyak menanam cabai ketika sesudah panen tanaman
Sustiyana, Iswahyudi 
padi dan pemanenan cabainya sudah masuk waktu musim kemarau. Selain itu adanya hama dan penyakit tanaman juga turut berpengaruh terhadap produktivitas tanaman cabai. Risiko teknologi juga dialami oleh petani, banyak petani cabai yang masih awam dengan perkembangan teknologi baik dari segi penanaman, pemupukan, hingga pemanenan (Misqi \& Karyani, 2020) .

Risiko harga yang fluktuatif memang dialami oleh tiap stakeholder yang terkait dalam rantai pasok komoditi cabai, termasuk petani yang posisinya paling lemah dalam menentukan harga (price taker) sehingga ketika harga pasar cabai sedang mahal maka petani akan meraup untung lebih banyak, sedangkan ketika harga cabai murah maka petani akan merugi.

Petani di daerah Kabupaten Sumenep tidak pernah melakukan kegiatan penyimpanan, setelah panen mereka akan langsung menjual kepada pengepul/ pedagang pengumpul untuk menghindari daya tahan buah cabai itu sendiri. Dalam pemilihan kerjasama dengan pengepul, petani juga mengalami risiko untuk memilih harga dan timbangannya karena ada oknum pengepul yang nakal dalam menentukan besaran timbangan walaupun harga belinya lebih tinggi daripada yang lainnya.

\section{b. Risiko di tingkat tengkulak/ pedagang pengumpul}

Risiko yang dialami oleh tengkulak didominasi oleh adanya distorsi informasi harga yang bergantung pada perubahan pasar dan jumlah pasokan juga berfluktuasi setiap waktu yang bergantung dari hasil produksi petani cabai. Semakin banyak hasil panen akan menurunkan harga cabai di pasar makro sehingga mempengaruhi harga di tingkat tengkulak dalam membeli produk cabai dari petani. Begitu pula sebaliknya ketika produk cabai mulai langka maka harga juga akan semakin mahal.

Pada risiko transportasi, hanya beberapa tengkulak skala besar yang mengalaminya saat dilakukan pengiriman barang ke luar daerah karena terjadi penumpukan barang pada mobil bak terbuka atau truk sehingga memicu kerusakan (Ahmad et al., 2018). Sedangkan pada tengkulak skala kecil tidak mengalami risiko transportasi karena biasanya pedagang besar yang langsung mendatanginya dengan membawa truk/mobil bak terbuka.

Risiko penyimpanan juga tidak begitu besar presentasenya karena produk cabai yang ada di tengkulak tidak disimpan dalam jangka waktu lama. Pengecekan ulang terhadap produk yang telah dibelinya dari petani sebelum dijual ke pedagang besar dan 
pedagang eceran harus dilakukan secara benar karena pasokan yang datang dari petani mutu/kualitasnya beragam. Walaupun sesama cabai tetapi ukuran, tingkat kematangan, dan jenisnya berbeda. Hal itu membutuhkan proses sortasi tambahan yang dilakukan oleh tengkulak agar meminimalkan kerugian.

\section{c. Risiko di tingkat pedagang besar}

Risiko yang dialami oleh pedagang besar tidak jauh berbeda dengan tengkulak. Hanya persentasenya lebih besar daripada pedagang perantara lainnya karena kuantitas yang diperdagangkan juga lebih besar. Jika risiko terjadi maka kerugiannya akan lebih besar tetapi jika pedagang tersebut dapat meminimalkan risiko maka keuntungan yang didapat juga jauh lebih besar daripada pedagang perantara lainnya (Analia, 2017).

Kondisi/mutu/kualitas

pasokan cabai juga berisiko untuk menimbulkan kerugian. Produk cabai yang rusak atau busuk akan menularkan pada produk cabai yang lainnya sehingga akan memicu kerugian. Oleh sebab itu Pedagang besar meskipun menyimpan produk cabai hingga siap kirim harus mempertimbangkan umur simpannya agar produk cabai tetap segar hingga sampai pada konsumen akhir.

Pedagang besar juga harus selektif dalam memilih tengkulak (mitra) yang berintegritas tinggi karena dapat menentukan keberhasilan perdagangan yang dilakukannya. Tengkulak yang tepercaya akan menyalurkan produk cabai yang bagus (tepat kualitas) dan tepat kuantitas. Ketika kuantitas cabai banyak maka pedagang besar juga mengalami risiko transportasi terutama jika produk dikirim ke luar Madura. Pedagang besar harus memastikan bahwa pasti ada pembeli besar lain di sana agar produknya terjual habis dengan waktu yang singkat. Hal ini juga berkaitan dengan faktor kerjasama antar pedagang besar di daerah Kabupaten Sumenep dengan di luar daerah.

Fluktuasi harga cabai terjadi karena ketersediaan cabai saat ini bersifat musiman, sedangkan kebutuhan cabai terjadi secara terus menerus. Dampak dari fluktuasi harga pada Pedagang Besar mempunyai persentase yang paling tinggi diantara stakeholder lain dalam rantai pasok cabai. Risiko terjadi saat pedagang besar telah memasok barang dengan harga tertentu tetapi tidak lama kemudian harga jualnya anjlok sehingga pedagang besar mengalami kerugian yang jauh lebih besar karena kuantitasnya juga besar.

\section{d. Risiko di tingkat pedagang eceran}

Risiko yang dialami oleh pedagang eceran juga tidak berbeda jauh dengan pedagang besar dan tengkulak. Perbedaannya terletak pada 
persentasenya yang paling rendah daripada pedagang lainnya (Gambar 1). Hanya saja aliran uang pada pedagang eceran merupakan yang paling lambat karena konsumen hanya membeli dalam jumlah sedikit.

\section{e. Risiko di tingkat konsumen}

Risiko terbesar yang dihadapi konsumen adalah fluktuasi harga terutama jika harga cabai meningkat maka akan mempengaruhi anggaran belanja keluarga maupun konsumen industri yang mempunyai usaha dengan memanfaatkan cabai sebagai bahan olahannya.

\section{Evaluasi Risiko Rantai Pasok Cabai}

Tahap evaluasi risiko sangat penting untuk dilakukan karena bisa dijadikan referensi dalam menentukan keputusan dalam meningkatkan kinerja rantai pasok cabai beserta meminimalkan risiko yang dialami oleh tiap stakeholder dalam rantai pasok tersebut. Evaluasi risiko dalam penelitian ini menggunakan persentase sederhana seperti yang tertera pada Gambar 1.

Berdasarkan hasil identifikasi secara menyeluruh dapat disimpulkan bahwa risiko tertinggi terletak pada tingkatan petani yang kemudian disusul oleh pedagang pada rantai pasok selanjutnya sebagaimana yang terlihat dalam diagram chart di bawah ini:

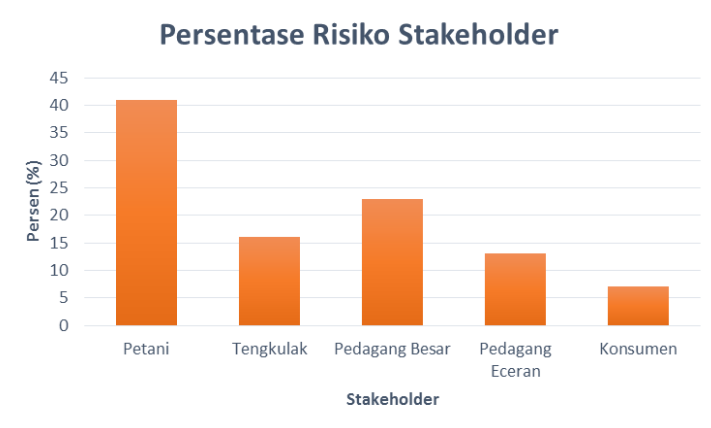

Gambar 1. Diagram perbandingan tingkatan risiko pada rantai pasok cabai

Dari Gambar tersebut menunjukkan bahwa risiko tertinggi dialami oleh petani cabai yaitu sebesar $41 \%$ sesuai dengan hasil identifikasi risiko sebelumnya dan didukung dengan hasil penelitian Sondakh et al. (2017). Penelitian tersebut menyebutkan bahwa petani merupakan penanggung risiko terbesar daripada stakeholder lainnya dalam rantai pasok. Cara meminimalkan risiko tersebut disesuaikan dengan jenis risikonya. Untuk risiko produksi dan kualitas dapat diatasi dengan penggunaan bibit unggul cabai, pemupukan yang sesuai dengan kondisi tanah dan penerapan teknologi yang tepat sehingga produk yang dihasilkan sesuai dengan yang diharapkan. Tetapi untuk risiko yang berkaitan dengan alam dan harga kurang bisa diatasi, perlu campur tangan pemerintah untuk menjaga keseimbangan harga pasar agar tidak merugikan petani.

Persentase risiko rantai pasok cabai yang dialami oleh pedagang besar merupakan yang tertinggi daripada
Sustiyana, Iswahyudi 
pedagang perantara lainnya yaitu sebesar $23 \%$, sedangkan tengkulak $16 \%$ dan pedagang eceran yang hanya $13 \%$. Seperti yang dijelaskan sebelumnya bahwa jenis risiko yang dialami oleh pedagang perantara itu sama hanya persentasenya saja yang berbeda sesuai dengan jumlah barang yang diperjualbelikan.

Konsumen mempunyai persentase yang paling kecil daripada stakeholder lainnya dalam rantai pasok cabai di Kabupaten Sumenep yaitu sebesar $7 \%$. Risiko yang dialami hanya pada risiko distorsi informasi mengenai fluktuasi harga, ketika harga cabai naik yang berkaitan dengan pasokan dan mutu produk sehingga konsumen rumah tangga maupun industri akan mengeluarkan uang lebih banyak untuk mendapatkan produk cabai.

\section{KESIMPULAN}

Berdasarkan penjelasan di atas dapat ditarik kesimpulan bahwa risiko rantai pasok tertinggi terdapat pada tingkat petani dengan persentase sebesar $41 \%$, pengepul $16 \%$, pedagang besar $23 \%$, pedagang eceran $13 \%$, dan konsumen $7 \%$. Faktor risiko yang paling dominan dialami oleh semua tingkatan rantai pasok yaitu risiko harga, risiko pasokan, dan risiko kualitas.

Disarankan setiap stakeholder yang terlibat dalam rantai pasok cabai di Kabupaten Sumenep harus lebih intensif dalam mengontrol risiko yang dihadapinya terutama risiko harga, pasokan, kualitas agar terhindar dari kerugian, karena jenis risiko tersebut saling berkaitan erat dan saling mempengaruhi.

\section{UCAPAN TERIMA KASIH}

Terimakasih disampaikan kepada Universitas Islam Madura yang telah mendanai kegiatan ini melalui hibah Penelitian Dosen Pemula (PDP) Tahun Anggaran 2019.

\section{DAFTAR PUSTAKA}

Ahmad, M., Febriska, F., \& Darus, D. (2018). Sistem Agribisnis dan Rantai Persediaan Cabai di Pekanbaru. Buletin Pembangunan Berkelanjutan, 2(1), 48-63.

Analia, D. (2017). Struktur Rantai Pasok (Supply Chain), Kelembagaan Dan Klaster Industri Komoditas Cabai: Sebuah Tinjauan Literatur. Agripita Journal, 1(1), 21-29.

Austin, J. (1992). Agroindustrial Project Analysis. The Johns Hopkins University. USA: Baltmore Press.

Badan Pusat Statistik. (2011). Bunga Rampai Statistik Percabaian. Katalog BPS. Jakarta

Bredell, R. D. (2008). Supply chain risk management: a logistics perspective. University of Johannesburg, Rand Afrikaans.

Indrajit, R. E., \& Djokopranoto, R. (2002). Konsep Manajemen Supply Chain: Cara Baru Memandang Mata Rantai Penyediaan Barang. Jakarta (ID): Grassindo. 
Kementrian Perdagangan. (2019).

Analisis Perkembangan Harga

Pangan Pokok di Pasar Domestik

dan Intenasional. Pusat

Pengkajian Perdagangan Dalam

Negeri. Jakarta.

Klimov, R., \& Merkuryev, Y. (2008). Simulation model for supply chain reliability evaluation.

Technological and Economic Development of Economy, 14(3), 300-311.

Misqi, R. H., \& Karyani, T. (2020). Analisis Risiko Usahatani Cabai Merah Besar (Capsicum Annuum L.) di Desa Sukalaksana Kecamatan Banyuresmi Kabupaten Garut. Mimbar Agribisnis: Jurnal Pemikiran Masyarakat Ilmiah Berwawasan Agribisnis, 6(1), 65-76.

Sondakh, J., Rauf, A. W., \& Rembang, J. H. (2017). Analisis Produksi Dan Rantai Pemasaran Jagung di Kabupaten Minahasa Selatan Provinsi Sulawesi Utara. Jurnal Pengkajian dan Pengembangan Teknologi Pertanian, 19(3), 213226.

Suharjito, S., Marimin, M., Machfud, M., Haryanto, B., \& Sukardi, S. (2010). Identifikasi dan Evaluasi Risiko Manajemen Rantai Pasok Komoditas Jagung dengan Pendekatan Logika Fuzzy. Jurnal Manajemen dan Organisasi, 1(2), 118-134.

Tang, C. S. (2006). Perspectives in supply chain risk management. International journal of production economics, 103(2), 451-488. 